\title{
Introduction to treatment guidance
}

Norman Sartorius

From $1^{\text {st }}$ International Congress on Neurobiology and Clinical Psychopharmacology and European

Psychiatric Association Conference on Treatment Guidance

Thessaloniki, Greece. 19-22 November 2009

This symposium will address the requirements that have to be satisfied if guidelines produced in the field of psychiatry are to be useful. One of the presentations will address this topic in general and another focus on guidelines that are being produced for research. A third presentation will exemplify the problems that might arise in the production of guidelines as well as the use to which they can be put by describing the experience gained by the National Institute of Clinical Excellence in the UK. It is expected that the symposium will lead to a full interaction between the speakers and the audience. Ethical issues that arise in connection with the application of guidelines will be highlighted in the introduction and in the concluding presentation by the chairpersons.

Published: 22 April 2010

doi:10.1186/1744-859X-9-S1-S51

Cite this article as: Sartorius: Introduction to treatment guidance. Annals of General Psychiatry 2010 9(Suppl 1):S51.

- Convenient online submission

- Thorough peer review

- No space constraints or color figure charges

- Immediate publication on acceptance

- Inclusion in PubMed, CAS, Scopus and Google Scholar

- Research which is freely available for redistribution 